\title{
Determining the Direction of the Pesantren (Empowering Leadership Practice at PM Gontor 6 Putera, Southeast Sulawesi)
}

\author{
Suryadi $^{1} \&$ Syahrul $^{2}$ \\ ${ }^{1}$ Universitas Negeri Jakarta \\ Email: hcsuryadi.unj@gmail.com \\ ${ }^{2}$ Institut Agama Islam Negeri Kendari \\ Email: syahrul.stain@gmail.com
}

\begin{abstract}
This article aims to understand the practice of empowering leadership, which is more specific on the theme of determining the direction of pesantren. The aspects studied are: 1) creating a vision; 2) describes the big picture; and 3) establishing a strategy. The investigation was carried out in the form of critical ethnography, where data were obtained through a process of observation, interviews, and document review. Data analysis was carried out through the description, analysis, and interpretation stages. This study found that: Empowering Leadership in the context of determining the direction of the organization at PM Gontor 7 Putera is a process of determining the vision and mission, explaining the big picture, and setting strategy. The roles carried out include being a strategic architect who defines PM Gontor's vision and mission, through internal and external environmental analysis, guarding a shared vision, overseeing the process of achieving a common vision at the functional level, as a figure who transforms strategy, who carries out the strategic communication process and makes appropriate measures, aligning strategies, to implementation. This research suggests the importance of building empowering leadership, having a strong vision, understanding internal and external dynamics, all of which can be formulated in an organizational strategy.
\end{abstract}

Keywords: Leadership, Empowerment, Vision, Strategy 


\title{
Menentukan Arah Pesantren \\ (Praktik Empowering Leadership di PM Gontor 6 Putera, Sulawesi Tenggara)
}

\author{
Suryadi $^{1} \&$ Syahrul $^{2}$ \\ ${ }^{1}$ Universitas Negeri Jakarta \\ Email: hcsuryadi.unj@gmail.com \\ ${ }^{2}$ Institut Agama Islam Negeri Kendari \\ Email: syahrul.stain@gmail.com
}

\begin{abstract}
Abstrak
Artikel ini bertujuan memahami praktik empowering leadership, yang lebih spesfik pada tema menentukan arah pesantren. Aspek-aspek yang didalami adalah: 1) penciptaan visi; 2) menjelaskan gambaran besar; dan 3) menetapkan strategi. Penyelidikan dilakukan dalam bentuk etnografi kritis, dimana data diperoleh melalui proses pengamatan, wawancara, dan telaah dokumen. Analisis data dilakukan melalui tahap deskripsi, analisis, dan interpretasi. Penelitian ini menemukan bahwa: Empowering Leadership dalam konteks menentukan arah organisasi di PM Gontor 7 Putera merupakan proses menentukan visi dan misi, menjelaskan gambaran besar, dan menetapkan strategi. Peran-peran yang dijalankan meliputi sebagai arsitek strategi yang mendefisinikasi visi dan misi PM Gontor, melalui analisis lingkungan internal maupun eksternal, penjaga visi bersama, mengawal proses pencapaian visi bersama pada level fungsional, sebagai figur yang mentrasformasi strategi, yang melakukan proses komunikasi strategi dan membuat ukuran-ukuran yang sesuai, menyelaraskan strategi, hingga implementasi. Penelitian ini menyarankan pentingnya membangun kepemimpinan yang memberdayakan, memiliki visi yang kuat, memahami dinamika internal dan eksternal, yang kesemuanya dapat dirumuskan dalam strategi organisasi.
\end{abstract}

Keywords: Kepemimpinan, Pemberdayaan, Visi, Strategi 


\section{Introduction}

Early discourses on organizations emphasized the importance of unity of purpose on the people within them (Robbins, 1990). Unity is even an important asset for future organizations (Morris \& Pitt, 1994). The results of studies on international organizations show that organizational growth requires the birth of decentralization, where these conditions increase conflict. Building unity of purpose can reduce institutional tension and fragmentation (McPeak, 2001). In organizations that are constantly moving and changing, leadership plays a role in determining the direction of the organization (Northouse, 2013:13).

The above point of view is shared by various organizations, profit and non-profit, including Islamic boarding schools, in this case PM Gontor, which started with the idea of "seeking the pleasure of Allah and advancing Muslims" (Syahrul, Mukhtar \& Akbar, 2018). With that spirit, PM Gontor has proliferated in various regions in Indonesia, so that it is considered the largest Islamic boarding school corporation in Indonesia (Syahrul, 2016). These various advances show the established culture of PM Gontor. However, leadership is the key to success in maintaining the culture of PM Gontor (Mardiyah, 2012). This means that the classic concept that the Kiai is the main element in the life of the pesantren is still valid (Mastuhu, 1994).

As a pesantren with a khalaf tradition (modern), PM Gontor shows different practices in its management. If generally Islamic boarding schools in Indonesia are managed by the Kiai family, then PM Gontor leaves it to the Muslims. Likewise, leadership success from the center to the branches is carried out openly, and is not chosen based on the Kiai lineage (Susilo, 2016). This practice is passed down in various aspects of PM Gontor management life, including various student activities that are not centralized, but empowering. Previous studies related to empowering leadership confirmed a positive relationship with the Leader-Member Exchange (LMX), affective commitment of subordinates, and perceptions of leadership effectiveness (Hasan, Mahsud \& Yukl, 2013).

The discourse of empowerment in pesantren life has been known since the early days. Prior to the establishment of the dormitory system, the students took care of their various needs independently. Especially when the number of santri is increasing and the Kiai is no longer able to bear their various needs (Madjid, 2011). 
Apparently, this tradition continues, although with a different model, for example community empowerment (Wekke, 2016). Kiai figures play an important role in empowering all pesantren resources (Pertiwi, Cahyani, Diana \& Gunawan, 2018). Human resource empowerment is an important agenda for pesantren, and has even been developed in a soft system methodology (Gunawan, Kusumaningrum \& Sumarsono, 2019). These HR empowerment roles remain the main domain in Kiai's leadership (Mukhtar \& Akbar, 2019).

Therefore, this article will provide an overview of leadership practices at PM Gontor 6 Putera, which are carried out with a spirit of empowerment, not only at the level of caregivers, but at the level of religious teachers and students, even the community around PM Gontor 6 Putera.

\section{Method}

The target of this research is empowering leadership in Pondok Modern Gontor 6 Putera Riyadhatul Mujahidin Southeast Sulawesi (in the following writing it will be abbreviated as PM Gontor 6 Putera). The unit of analysis is the Kiai who plays the role of Deputy Caretaker at PM Gontor 6 Putera. While the objects are residents of PM Gontor 6 Putera.

This research is a qualitative study, with a critical ethnographic method. This is based on the scope of the problems that have been stated previously and the suitability of the criteria, namely: value orientation, empowering, and various power problems. Data collection was carried out through interviews, observation and document study. Meanwhile, data analysis was carried out in stages: description, analysis, and interpretation (Creswell \& Poth, 2016). At the analysis stage, Creswell suggests using the analysis developed by Spradley, namely: domain analysis, taxonomic analysis, compound analysis, and cultural theme analysis (Spradley, 2016).

Testing the validity of the data is done through triangulation, member checks, extended observations, and increased perseverance (Sugiyono, 2005).

\section{Results and Discussion}

The elements of leadership in determining the direction of the organization include 3 (three) aspects, namely: creating a vision, explaining the big picture, and establishing a strategy (Northouse, 
2018). The findings related to Kiai's leadership in determining the direction of PM Gontor 6 Putera are as follows:

1. Kiai as strategic architect who defines PM Gontor's vision and mission, through internal and external environmental analysis.

2. Kiai as guardians of the shared vision, overseeing the process of achieving the shared vision at the functional level.

3. Kiai as a figure who transforms strategy, who carries out the strategy communication process and makes appropriate measures, aligns strategy, to implementation.

4. Kiai as manager of all PM Gontor resources directed to implement the strategy.

The four findings will be explained as follows:

\section{A. Strategy Architecture}

Strategy architecture is the stage of synthesizing strategic input, both in the form of direction and magnitude of the strategy. This process is the design and architect of the strategy, more in the "what" process of the strategy, which includes: 1) Strategic destination, which is the process of defining and synthesizing the destination / direction of the strategy to be built, which usually includes the vision and mission of the organization. ; 2) strategic thinking, namely the environmental analysis process, both internal and external; 3) strategy formation, namely the process of designing a strategy based on the direction and position obtained from strategic destinations and strategic thinking (Hutabarat \& Huseini, 2006).

Strategic destination has been widely practiced in business organizations in order to build an image for customers, one of which is in the tourism sector. This method helps organizations to read the future of their business (Formica \& Kothari, 2008). Improving the quality of business requires a large-scale, long-term planning, resulting in the need for education and training (Peters \& Buhalis, 2004). In the world of education, strategic destinations are needed in the context of internationalizing educational institutions, especially in universities (Rudzki, 1995).

Strategic thinking also leads to strengthening the image of the organization in society (Zahra \& Nambisan, 2012). In the business world, strategic thinking helps analyze the factors that determine customer satisfaction including their loyalty (Sasono, 2006). 
In the context of the Kiai's leadership at PM Gontor 7 Putera, the strategic architecture was initiated by the founders, who emphasized that the basic objective of PM Gontor's establishment was in the responsibility of advancing Muslims and seeking the pleasure of Allah. The condition of the Muslims who were left behind in education at that time, became the reason for the founders of Gontor to build an educational institution that was not only local, but global. So PM Gontor was born which was a synthesis of the Al-Azhar, Santiniketan, Alighar, and Syanggit education systems.

The initial ideals of PM Gontor's establishment were based on a sense of social responsibility and a divine orientation, a non-material orientation. This is in line with the view of Stoner et al that organizations that have social responsibility seek to influence the surrounding community with various activities and voluntary assistance (Stoner, Freeman, \& JR, 1996). Social responsibility also means that an institution has a social obligation that can be seen in policies, decision-making, and actions that benefit society (Williams, 2001).

Not only social obligations, organizational social responsibility also includes social reaction and social responsiveness. In the context of social obligations, the community is considered as a supporter and giver of permission to establish an organization. So that the community has the right to benefit from the organization. From the point of view of social reactions, an organization works due to the norms, values, and expectations of today's society (Gibson, Ivancevich, Donnelly, \& Konopaske, 2012).

The view that social responsibility is a social obligation is supported by several reasons, which can be transferred to non-profit organizations or public organizations. First, the institution is responsible for its owner, namely the government, where this is a manifestation of service to the state and society. Second, as socially responsible activities or social improvement. Therefore it must be strengthened through regulations, public policies, individual actions and contributions. Third, organizational activities are social works, so that the products produced and their services lead to the interests of the community. Fourth, the sustainability of an organization in the future is influenced by economic and non-economic factors, so that in order to survive an organization must be able to calculate profit and 
loss and customer expectations (Gibson, Ivancevich, Donnelly, \& Konopaske, 2012).

The World Bank defines Social Responsibility as the commitment of a business to contribute to sustainable economic development, by working with employees and their representatives, both local and public, to improve the quality of life in ways that benefit both the business itself and development. CSR components based on World Bank standards include (1) environmental protection (2) job security (3) Human Rights (4) company interaction and involvement with the community (5) business standards (6) market (7) economic development and business entities ( 8) health protection (9) leadership and education (10) humanitarian disaster relief. For companies that are trying to build a positive image of their company, the ten components must be fulfilled. The Ministry of Social Affairs of the Republic of Indonesia defines CSR as the commitment and ability of the business world to provide care, carry out social obligations, build togetherness, carry out social welfare programs/activities, social development of community welfare as a form of social solidarity and maintain the balance of the surrounding ecosystem (Zulkifli, 2017).

The World Bank states that the quality of education in Indonesia is still low, although the expansion of access to education for the community is considered to have increased quite significantly. Indonesia itself has launched an education reform program to improve the quality of this sector for 15 years since 2002. World Bank Representative for Indonesia Rodrigo Chaves said the low quality of education is reflected in Indonesia's ranking which is still in the highest position compared to neighboring countries. This education quality rating indicator is reflected in the number of illiteracy cases. Especially for the quality of education, the challenge in many countries is the management and effectiveness of children's learning in schools. Likewise with the curriculum and text books, it is important that the state can prepare a strategy in developing human resources with existing challenges, such as industrialization, changing technology, and information disclosure (Fauzie, 2018).

Findings about Kiai's leadership in maintaining the tradition of the cottage can be said to be a reflection of PM Gontor's long history. Lessons from the past are instrumental in working for all residents of 
the lodge. Some of the aspects included in Kiai's leadership in caring for the cottage culture are as follows:

1. Revitalizing the ideas of Tegal Sari

2. Reproduction of the movement of change in the Old Gontor era

3. Instilling shared values

4. Ground shared values

5. PM Gontor expansion.

Findings about Kiai's leadership in building institutional relevance can be seen as a leader's responsiveness to contemporary changes. This response marks the social responsibility of the pesantren, also in order to maintain the quality (Syahrul, 2017). Because quality is always related to the needs of society, in this case the customers. The job of every organization is to provide services and products that can satisfy customers, even exceed their expectations (Syahrul, 2013).

\section{B. Shared Vision}

A shared vision is a shared picture of the future, directed principles and practices to achieve goals, and most importantly the building of commitment within the group (Senge, 1995). In the context of learning organizations, a shared vision is the third pillar. The other four pillars are: 1) personal mastery, which is learning to expand personal capacity, creating an organizational environment that encourages everyone to achieve the desired goals; 2) mental models, namely reflecting continuously, improving internal images of the world, and how these images affect behavior; 3) team learning, where a collective thinking and dialogue skill is transformed, so that people collectively can develop their skills and abilities; 4) system thinking, is a way of thinking and language to describe and find out the strengths and relationships that influence behavior. Systems thinking will help to see system changes effectively and take appropriate action in larger systems (Senge, 1995).

A common vision can help an institution, even a state, in carrying out a change process, such as educational reform (Ishaq, 2006). In leadership practice, efforts to build cooperation within the organization are largely determined by a common vision (Sulasmi, 2008). In a more micro context such as learning for students, the same vision simultaneously with the variable intensity of cooperation and innovative learning behavior will strengthen synergy in building quality learning (Sulasmi, 2008). 
Therefore, it is very important in inspiring a common vision (Martin, McCormack, Fitzsimons, \& Spirig, 2014). Communication is the key word in achieving a common vision (Farmer, Slater, \& Wright, 1998). In the shared vision there are factors that attract positive emotions as a conduit for effective leadership, relationships between members, and their involvement in the organization (Boyatzis, Rochford, \& Taylor, 2015).

A shared vision is a tool for developing a learning organization (Hoe, 2007), not a dream but reality (Hodgkinson, 2007), whose role is to create a professional learning society (Huffman, 2003). Creating a learning society is the result of the interaction between shared leadership, shared vision, and supportive conditions (Huffman \& Hipp, 2001). Issues in educational technology such as engagement, empowerment, and activation will be realized if starting from a common vision (Romeo, 2006).

In the context of Kiai's leadership at PM Gontor 6 Putera, related to a very strong orientation on a shared vision, he shows his determination to make PM Gontor a learning organization.

\section{Strategy Transformation}

Strategy transformation is the process of communicating strategies and making appropriate measurements, aligning with the strategy, then regarding alignment after implementation (Hutabarat \& Huseini, 2006). The flexibility of the strategy can assist in its application to real-life organizations over time.

Strategy transformation is the stage of translating the strategy into implementation, including the parameters used must be represented in the strategy and implementation. Strategy transformation must be able to create synergies from various functions and elements of the organization so that they are more motivated and motivated in realizing and implementing strategies (Hutabarat \& Huseini, 2006).

The strategic transformation that is very often used today is the Balanced Score Card (BSC) introduced by Robert Kaplan and David Norton, which contains four perspectives on strategy to be transformed into implementation, namely: financial, customer, process internal business, and growth and learning (Kaplan \& Norton, 2005). The directions from these four perspectives can be seen in the following figure: 


\begin{tabular}{|l|l|}
\hline Financial $\longrightarrow$ & $\begin{array}{l}\text { What our shareholder expectations for } \\
\text { financial performance? }\end{array}$ \\
\hline Customer $\longrightarrow$ & $\begin{array}{l}\text { To reach our financial objective, how do } \\
\text { we create value for our customers? }\end{array}$ \\
\hline Internal Process $\longrightarrow$ & $\begin{array}{l}\text { What processes must we excel at to } \\
\text { satisfy our customers and shareholders? }\end{array}$ \\
\hline Learning \& Growth $\rightarrow$ & $\begin{array}{l}\text { How do we align our intangible assets } \\
\text { (people, sysmtem and culture) to improve } \\
\text { the critical processes? }\end{array}$ \\
\hline
\end{tabular}

Figure 1. Description of the Four Perspectives in a Balanced Scorecard

Source: Rober S. Kaplan dan David P. Norton dalam Aligment: Using the Balanced Scorecard to Create Corporate Synergies (Kaplan \& Norton, 2006).

The four perspectives in the balanced scorecard interact with each other in order to implement the strategy and achieve the organization's vision, as shown in the following figure:

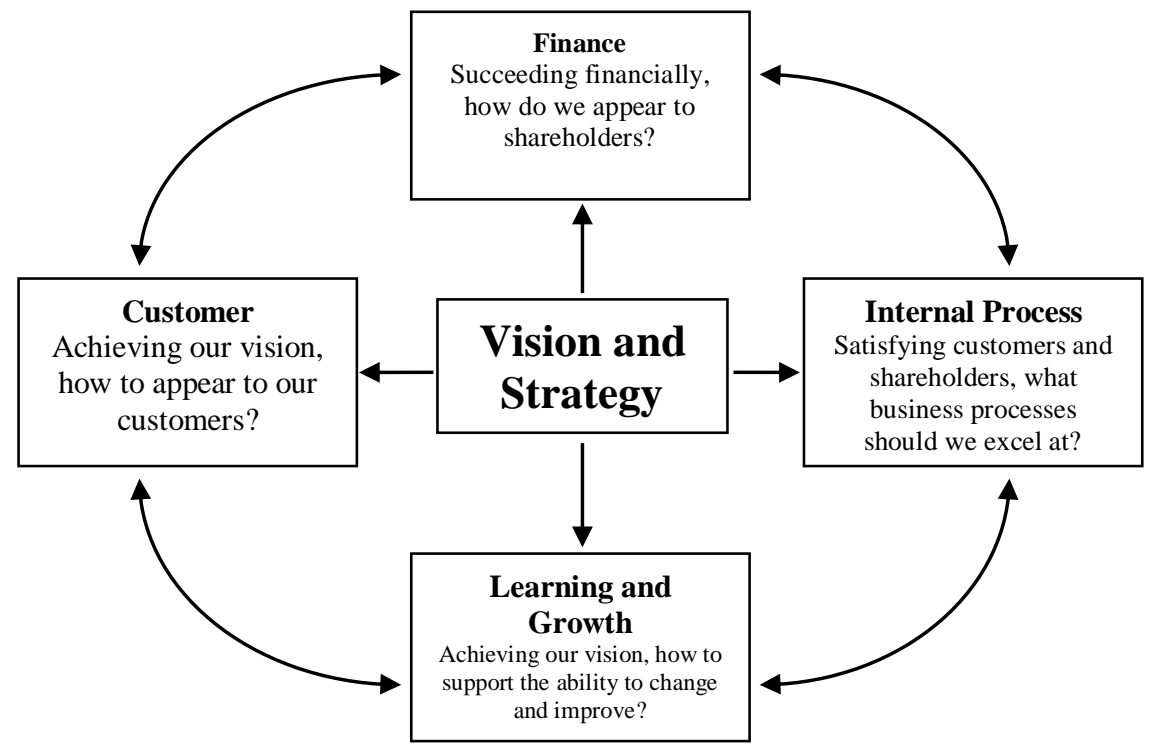

Figure 2. Balanced Scorecard Process and Interaction 


\section{Managing Organizational Resources}

In the context of strategy, managing organizational resources is at the strategy implementation stage, namely the "how to" process of the strategy. This activity involves all organizational resources that are mobilized to implement the strategy (Hutabarat \& Huseini, 2006). The diversity of human resources can be a very useful input in improving organizational performance (Hartini, 2012). No less important is managing knowledge and intellectual capital (Djajadiningrat, 2005).

Human resource management requires an understanding of the inherent characteristics of humans which include demographic characteristics and biographical characteristics. Therefore, the diversity of human resources can be categorized into 2 (two) levels. First, surface-level diversity, differences in easily understood characteristics, such as gender, race, ethnicity, age, or disability, which do not necessarily reflect the way people think or feel but can activate certain stereotypes (differences in easily). perceived characteristics, such as gender, race, ethnicity, age, or disability, that do not necessarily reflect the ways people think or feel but that may activate certain stereotypes. Biographical characteristics are diversity at the surface level. Second, deep-level diversity, namely differences in values, personalities, and work preferences which are very important to determine similarities when people know each other (differences in values, personality, and work preferences that become progressively more important for determining similarity as people get to know one another better). Demographic characteristics are included in the deep level diversity (Robbins \& Judge, 2013).

Research findings related to Kiai's leadership in human resource management are a manifestation of the Kiai's perspective on the human element as the backbone of Islamic boarding school activities. Some of the aspects of this perspective are as follows:

1. A view of humans.

2. Making use of ideas.

3. Empowerment of members.

4. Reward system.

The assumptions in human resource management include several aspects: 1) The organization exists in order to serve human needs, not the other way around, 2) The needs of organizations and people for each other. In this case the organization's need for ideas, 
energy and talent. Whereas people need careers, salaries and opportunities, 3) When the fit between individuals with systems is low, one or both suffer. Individuals exploited or exploited the organization, or both become victims, 4) The balance of benefits for both organization and people. Individuals find meaning and job satisfaction, while organizations get the talent and energy they need (Bolman \& Deal, 2017).

The HR department (human resources) in an organization / company plays an important role. The section that is tasked with performing human resource management has a major responsibility for each employee in relation to the performance given to the company. Not only that, this section is also the main bridge between the company and employees, and vice versa (Camps \& Luna-Arocas, 2012).

Human resources, in contrast to machines or robots, can be managed by applying the same template program. Humans need to be treated as humans, in order to maximize their performance (Dwiyanto, 2018). When viewed in terms of the urgency of HR management, here are some important points that need to be understood.

First, institutional culture. HR management within the company must be done carefully. The work culture within the company is created by engineering the HR department and cooperating with every other department. This culture is certainly considered the most effective, so that employees can feel comfortable when working at the company (Jekiel, 2020). Second, capacity and working time. The HR department will have to make a formula in such a way, so that employees can adapt the predetermined work culture. Ideally employees will provide maximum performance when employees can be compact and work in line with the existing culture (Steinmetz, Vries, \& Tijdens, 2014). Third, incentives and salaries. HR management does not stop at the two previous sections, but also includes financial matters. The provision of incentives and salaries to employees must also be taken into account by reflecting on the labor market and employee achievements every month. Of course the company must provide a decent salary, but not too far from the standard reference in the regional salary. This applies to both parties. On the one hand, for employees, the amount of salary and incentives will increase work comfort and loyalty to the company. On the company side, the right salary calculation will make the allocation of 
resources in the form of funds effective and in accordance with the company's production costs. High attention to incentives and salaries by an institution / company will have an impact on work productivity (Irawan, 2018). Fourth, employee activities. Every employee activity should be well planned and conceptualized. This activity, if managed properly, will have a positive effect on both parties. Employee cohesiveness will increase engagement between employees which leads to increased job satisfaction and work comfort. Of course, with a compact employee, the company will get better output. Planned activities such as field trips, celebrations, team building and other activities that involve every element of employees can be a real form of efforts to increase cohesiveness among employees (Tepayakul \& Rinthaisong, 2018). Fifth, advocacy. Without human resource management, there is no so-called advocacy process. Usually this should be done when employees have problems with the company, or vice versa. The HR department must take full responsibility for this matter and help both parties find an agreement. HR management also includes this advocacy process, so it is important to have it in every company. As employees, the right to fight for interests must be guaranteed. Likewise, as a company, the right to demand the fulfillment of targets must be pursued. The HR department must be able to harmonize the two parties so that each of their rights can be fulfilled without having to go through a legal legal process in court (Chen, et al., 2004). A description of the Kiai's leadership in determining the direction of PM Gontor 6 Putera, can simply be seen in the following picture.

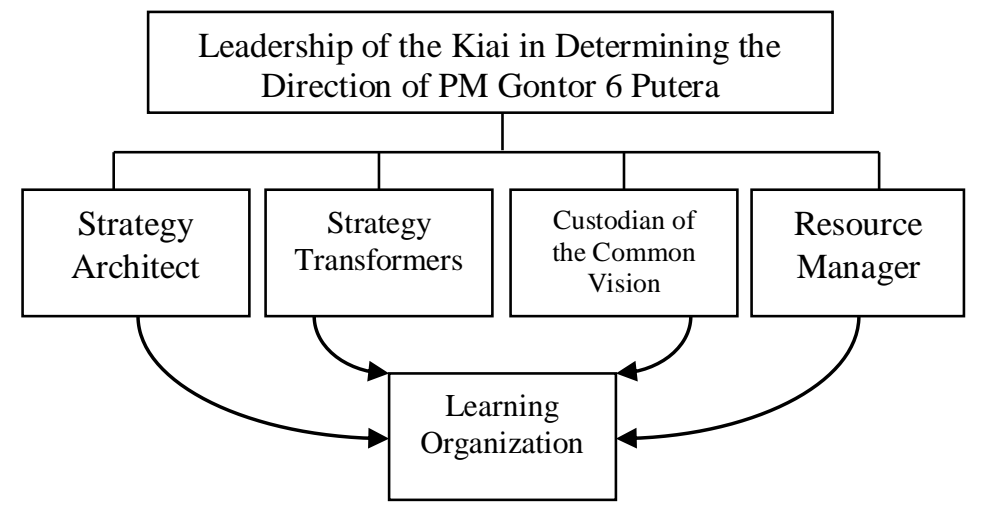

Figure 3. Leadership of the Kiai in Determining the Direction of PM Gontor 


\section{Conclusion}

Determining the direction of the organization is the main task of a leader, where the leadership function will be seen. The vision of the organization becomes a guide in formulating the vision of the leader, so as to create unity between the leader and the organization. Since the organization's vision has generally been formulated previously, the next task is to define the vision so that it can be understood by all members and various levels of society. In this context, a shared vision, a view of the future that will be achieved together. Therefore, it is necessary to guard a shared vision up to the functional level. Vision is reduced to strategy, starting from formulation, implementation, to strategy evaluation. The empowerment process becomes the spirit in determining the direction of the organization. The implication of this perspective is the need to determine the direction of the organization in leadership practice. More importantly, empowering leadership needs to be a model in the development of educational institutions.

\section{REFERENCES}

Bolman, L. G., \& Deal, T. E. (2017). Reframing organizations: Artistry, choice, and leadership. John Wiley \& Sons.

Boyatzis, R. E., Rochford, K., \& Taylor, S. N. (2015). The role of the positive emotional attractor in vision and shared vision: toward effective leadership, relationships, and engagement. Frontiers in Psychology 6, 670.

Camps, J., \& Luna-Arocas, R. (2012). A matter of learning: How human resources affect organizational performance. British Journal of Management 23, no. 1, 1-21.

Chen, L., Evans, T., Anand, S., Boufford, J., Brown, H., Chowdhury, M., et al. (2004). Human resources for health: overcoming the crisis. The Lancet, 364(9449) , 1984-1990.

Creswell, J. W., \& Poth, C. N. (2016). Qualitative inquiry and research design: Choosing among five approaches. Sage publications.

Djajadiningrat, S. T. (2005). Mengelola Pengetahuan dan Modal Intelektual dengan Pembelajaran Organisasi: Suatu Gagasan untuk Institut Teknologi Bandung. Orasi Ilmiah pada Sidang 
Terbuka ITB Peringatan Dies Natalis Institut Teknologi

Bandung ke-46, tanggal 2.

Dwiyanto, H. (2018). Manajemen Sumber Daya Manusia Madani di Universitas Negeri. Manajemen Pertahanan 3, no. 2 .

Farmer, B. A., Slater, J. W., \& Wright, K. S. (1998). The role of communication in achieving shared vision under new organizational leadership. Journal of public relations research 10, no. $4,219-235$.

Fauzie, Y. Y. (2018, Juni 7). Bank Dunia: Kualitas Pendidikan Indonesia Masih Rendah. Dipetik Juni 11, 2018, dari https://www.cnnindonesia.com/gaya-hidup/20180607113429284-304214/bank-dunia-kualitas-pendidikan-indonesia-masihrendah.

Formica, S., \& Kothari, T. H. (2008). Strategic destination planning: Analyzing the future of tourism. Journal of Travel Research 46, no. $4,355-367$.

Gibson, J. L., Ivancevich, J. M., Donnelly, J. H., \& Konopaske, R. (2012). Organizations: Behavior, Structure, Processes, Fourteenth Edition. McGraw-Hill.

Gunawan, I., Kusumaningrum, D. E., \& Sumarsono, R. B. (2019, December). Investigation of Principal Leadership Based on Pesantren: Descriptive Study about Implementation of Human Resources Empowerment Models Based on Soft System Methodology. In The 4th International Conference on Education and Management (COEMA 2019) (pp. 255-258). Atlantis Press.

Hartini, T. (2012). Mengelola Keragaman Sumberdaya Manusia: Suatu Upaya Mengoptimalkan Kinerja Organisasi. In Forum Bisnis Dan Kewirausahaan Jurnal Ilmiah STIE MDP, vol. 1, no. 2, , 84-92.

Hassan, S., Mahsud, R., Yukl, G., \& Prussia, G. E. (2013). Ethical and empowering leadership and leader effectiveness. Journal of Managerial Psychology.

Hodgkinson, M. (2007). A shared strategic vision: dream or reality?." The learning organization.

Hoe, S. L. (2007). Shared vision: a development tool for organizational learning. evelopment and Learning in Organizations: An International Journal. 
Huffman, J. B., \& Hipp, K. A. (2001). Creating communities of learners: The interaction of shared leadership, shared vision, and supportive conditions. International Journal of Educational Reform 10, no. 3 , 272-281.

Huffman, J. (2003). The role of shared values and vision in creating professional learning communities. Nassp Bulletin 87, no. 637 , 21-34.

Hutabarat, J., \& Huseini, M. (2006). Operasionalisasi Strategi. Jakarta: PT. Elex Media Komputindo.

Irawan, M. R. (2018). Pengaruh Gaji dan Insentif terhadap Produktivitas Kerja Karyawan pada PT. Mahkota Sakti Jaya Sidoarjo. Ecopreneur. 12: Journal Economic and Business, 1(1) , 36-41.

Ishaq, I. (2006). Ishaq, Isjoni. Membangun visi bersama: aspek-aspek penting dalam reformasi pendidikan. Jakarta: Yayasan Obor Indonesia.

Jekiel, C. M. (2020). Lean human resources: redesigning $H R$ processes for a culture of continuous improvement. CRC Press.

Kaplan, R. S., \& Norton, D. P. (2005). The Balanced Scorecard: Measures that Drive Performance. Harvard Business Review On Point.

Kaplan, R. S., \& Norton, D. P. (2006). Aligment: Using the Balanced Scorecard to Create Corporate Synergies. Boston, Massachusetts: Harvard Business School Press.

Madjid, D. N. (2011). Bilik-Bilik Pesantren: Sebuah Potret Perjalanan. Jakarta: Paramadina.

Mardiyah, M. (2012). Kepemimpinan Kiai dalam Memelihara Budaya Organisasi di Pondok Modern Gontor, Lirboyo Kediri, dan Pesantren T ebuireng Jombang. Tsaqafah, 8(1), 67-104.

Martin, J., McCormack, B., Fitzsimons, D., \& Spirig, R. (2014). The importance of inspiring a shared vision. International Practice Development Journal 4, no. 2 .

Mastuhu. (1994). Dinamika Sistem Pendidikan Pesantren: Suatu Kajian tentang Unsu dan Nilai Sistem Pendidikan Pesantren. Jakarta: INIS.

McPeak, M. (2001). Tackling fragmentation and building unity in an international nongovernmental organization. Nonprofit Management and Leadership, 11(4), 477-491. 
Morris, M. H., \& Pitt, L. F. (1994). The organization of the future: unity of marketing and strategy. Journal of Marketing Management, 10(7), 553-560.

Mukhtar, M., \& Akbar, M. (2019, December). Kiai's Leadership in Managing Human Resources. In 3rd International Conference on Education Innovation (ICEI 2019) (pp. 79-82). Atlantis Press.

Northouse, P. G. (2018). Kepemimpinan : Teori dan Praktik. Edisi Keenam. Penerjemah: Dr. Ati Cahayani. Jakarta: Indeks.

Pertiwi, A. K., Cahyani, S. S. A., Diana, R. C., \& Gunawan, I. (2018, October). The Leadership of Kyai: A Descriptive Study. In 3rd International Conference on Educational Management and Administration (CoEMA 2018) (pp. 121-126). Atlantis Press.

Peters, M., \& Buhalis, D. (2004). Family hotel businesses: strategic planning and the need for education and training. emerald.com.

Robbins, S. P. (1990). Organization Theory: Structures, Designs, And Applications, 3/e. Pearson Education India.

Robbins, S. P., \& Judge, T. A. (2013). Organizational behavior (Vol. 4). New Jersey: Pearson Education.

Romeo, G. (2006). Engage, empower, enable: Developing a shared vision for technology in education." In Engaged learning with emerging technologies. Springer, Dordrecht, 149-175.

Rudzki, R. E. (1995). The application of a strategic management model to the internationalization of higher education institutions. Higher Education 29, no. 4 , 421-441.

Senge, P. M. (1995). Learning organizations. Cambridge: Gilmour Drummond Publishing.

Stoner, J. A., Freeman, R. E., \& JR, D. R. (1996). Manajemen. Jakarta: PT. Prenhallindo.

Steinmetz, S., Vries, D. H., \& Tijdens, K. G. (2014). Should I stay or should I go? The impact of working time and wages on retention in the health workforce. Human resources for health 12, no. 1 , 23.

Susilo, A. (2016). Kontribusi Waqf Gontor Terhadap Kesejahteraan Masyarakat Desa Gontor. Islamic Economics Journal, 2(1), 1735.

Sulasmi, S. (2008). Sulasmi, Siti. "Pengaruh Kepemimpinan Membangun Semangat Kerjasama Dengan Kebersamaan Visi 
Sebagai Variabel Moderator. urnal Ekonomi dan Bisnis Airlangga (JEBA) 18, no. 1 .

Syahrul, S. (2013). Penelitian sebagai Instrumen Perbaikan Kualitas Kinerja Organisasi Pendidikan secara Berkelanjutan (Continuous Improvement). Al-TA'DIB: Jurnal Kajian Ilmu Kependidikan, 6(1), 150-163.

Syahrul, S. (2016). Kepemimpinan Religio-Transformasional: Altruisme Kiai dalam Membangun Karakter dan Budaya PM Gontor VII Putra Sulawesi Tenggara.

Syahrul. (2017). Tanggung Jawab Sosial Pesantren: Studi pada Pondok Pesantren Al Munawwarah Pondidaha, Konawe. . Shautut Tarbiyah, Vol. 23, No. 2, 120-134.

Syahrul, S., Mukhtar, M., \& Akbar, M. (2018). Construction of Organizational Culture at PM Gontor VII Putera, South Konawe District, Southeast Sulawesi, Indonesia. International Journal of Advanced Engineering and Management Research, 3(5), 25-40.

Tepayakul, R., \& Rinthaisong, I. (2018). Job satisfaction and employee engagement among human resources staff of Thai private higher education institutions. The Journal of Behavioral Science 13, no. 2 , 68-81.

Wekke, I. S. (2016). Religious education and empowerment: study on pesantren in muslim minority West Papua. MIQOT: Jurnal Ilmu-ilmu Keislaman, 37(2).

Williams, C. (2001). Manajemen. Penerjemah: M. Sabaruddin Napitupulu. Jakarta: Salemba Empat.

Zahra, S. A., \& Nambisan, S. (2012). Entrepreneurship and strategic thinking in business ecosystems. Business horizons 55, no. 3 , 219-229.

Zulkifli, A. (2017, April 23). bangazul.com. Dipetik May 2018, dari Definisi Tanggung Jawab Sosial: https://bangazul.com/definisitanggungjawab-sosial-atau-corporate-social-responsibility/ 